\title{
Isolation and Characterization of Rhesus Monkey Milk Lactoferrin
}

\author{
LAURIE A. DAVIDSON AND BO LÖNNERDAL \\ Department of Nutrition and California Primate Research Center, University of California, Davis, California \\ 95616
}

\begin{abstract}
Rhesus monkey milk lactoferrin was isolated and its characteristics compared with those of human milk lactoferrin in order to assess the feasibility of using the rhesus monkey as an animal model for the study of iron absorption from milk. Monkey lactoferrin was isolated from pooled monkey milk by two chromatographic steps. Concentration of lactoferrin in milk, determined by rocket immunoelectrophoresis, demonstrated similar concentrations in both human and monkey milk, 1-2 mg/ml. Immunodiffusion of lactoferrins from several species using an antibody raised to money lactoferrin resulted in a crossreaction only with monkey and human lactoferrin. Lactoferrins from cow, sheep, goat, dog, and rat milk were not recognized by the antibody. Amino acid analysis of monkey lactoferrin showed a composition very similar to human lactoferrin, as well as a similarity in the unusual amino acid sequence at the $\mathrm{N}$-terminal of the protein. The carbohydrate moiety of monkey lactoferrin was investigated and shown to contain monosaccharides in similar proportions to those reported for human lactoferrin. In our opinion, the rhesus monkey is a promising model for the study of the role of lactoferrin in iron absorption in the infant, as well as of the other proposed actions of lactoferrin. (Pediatr Res 20: 197-201, 1986)
\end{abstract}

It has been documented that the absorption of iron from human milk is more efficient than from infant formulas based on cow's milk or soy protein $(1,2)$. The high degree of iron absorption from breast milk is manifested in a low incidence of iron-deficiency anemia among breast-fed infants. In contrast, infants consuming cow's milk formula without supplemental iron display a higher incidence of iron deficiency during the early months of life (3).

This high iron absorption from human milk is thought to be due to a higher bioavailability of the trace element from human milk. Despite the fact that the iron content of human milk and cow's milk are similar $(4,5)$, iron absorption from human milk has been observed to be three to five times higher than from cow's milk in both infants and adults $(1,2)$. Lactoferrin, the major iron-binding protein in human milk, has been implicated as a possible factor contributing to the high bioavailability of iron. Lactoferrin is similar in several physical and chemical properties to transferrin and has been shown to be present in various exocrine secretions (nasal, lacrimal, vaginal, bronchial) (6), in pancreatic juice and in specific granules of neutrophils (7). Both lactoferrin and transferrin can bind two ferric ions with high affinity. The binding constant of lactoferrin for iron is $\sim 10^{30}$ with iron not being completely released until the $\mathrm{pH}$ is lowered

Received Junc 24, 1985; accepted October 7, 1985.

Reprint requests Dr. Bo Lönnerdal. Department of Nutrition, University of California, Davis, Davis, CA 95616. to 2 (8). This high affinity for iron is thought to provide a mechanism for a bacteriostatic effect by lactoferrin since iron is a required nutrient for many microorganisms. It has been demonstrated in an in vitro system that lactoferrin can inhibit the growth of several strains of bacteria, including Escherichia coli and Staphylococcus aureus (9). This effect is abolished if the protein is saturated with iron, indicating it is the iron-binding ability of lactoferrin that gives it the bacteriostatic property.

In vitro data show lactoferrin to be relatively resistant to proteolysis and low $\mathrm{pH}(10,11)$ and there is evidence for the survival of intact lactoferrin during passage through the gastrointestinal tract of the infant $(12,13)$. These unique characteristics provide additional support for a bacteriostatic role for lactoferrin in the infant.

Lactoferrin has also been suggested to play a role in the immune system. The protein has been shown to bind specifically to human monocytes (14), polymorphonuclear leukocytes (15), and macrophages (16) and may be involved in several aspects of the inflammatory response.

In the present study we have investigated the use of an animal model in studying the role of lactoferrin in iron absorption since ethical considerations prevent the use of human infants in studies involving radioisotopes or necessitating the use of tissue samples. It has been shown previously that lactoferrins from human and bovine milk have different abilities to donate iron to human mucosa in an in vitro system (17). Therefore, it is essential to study lactoferrins with similar characteristics to the human protein in order to draw parallels to the role lactoferrin may play in iron absorption in the human.

In contrast to most species, lactoferrin concentration in both human and monkey milk is quite high, in the range of $1-2 \mathrm{mg} /$ $\mathrm{ml}(18,19)$. Monkey lactoferrin was isolated and its chemical and physical characteristics investigated in order to assess the feasibility of using the rhesus monkey as a model in the study of iron absorption from milk.

\section{MATERIALS AND METHODS}

Isolation of monkey lactoferrin. Pooled monkey milk $(75 \mathrm{ml})$ was obtained from the California Primate Research Center, University of California, Davis, and was centrifuged at 15,000 $\times$ $g$ for $30 \mathrm{~min}$. The fat layer and casein pellet were removed and the resulting whey was made $2 \mathrm{M}$ with ammonium sulfate, stirred for $20 \mathrm{~min}$, and centrifuged at $10,000 \times \mathrm{g}$ for $30 \mathrm{~min}$. The lactoferrin containing supernatant was brought to $75 \%$ saturation $(4.4 \mathrm{M})$ with ammonium sulfate and centrifuged for $30 \mathrm{~min}$ at $10,000 \times g$. The resulting pellet was dissolved in $0.05 \mathrm{M}$ Tris$\mathrm{HCl}, \mathrm{pH} 9.2$; iron was added to saturate the lactoferrin $(2 \mathrm{~mol}$ ferrous ammonium sulfate per mol lactoferrin) and sodium bicarbonate added to promote iron-binding to the protein $(1 \mathrm{~mol}$ bicarbonate per mol iron) (20). The resulting solution was dialyzed against the Tris buffer until its ionic strength was identical to that of the buffer. This crude lactoferrin solution was chromatographed on a DEAE-Sephadex A-25 ion exchanger $(15 \times 2$ 
$\mathrm{cm}$ ) in $0.05 \mathrm{M}$ Tris- $\mathrm{HCl}, \mathrm{pH} 9.2$, employing a linear gradient of $0-0.5 \mathrm{M} \mathrm{NaCl}(400 \mathrm{ml}$ plus $400 \mathrm{ml})$. The lactoferrin peak, identifiable by its pink color, was pooled, dialyzed against the starting buffer, and applied to a Heparin-Sepharose affinity column $(6 \mathrm{ml})$, purchased from Pharmacia Fine Chemicals (Uppsala, Sweden). The column was eluted with a stepwise gradient of the same buffer containing $\mathrm{NaCl}(0-1.0 \mathrm{M})(21)$.

Purity of the monkey lactoferrin. Purity of the isolated monkey lactoferrin was assessed by polyacrylamide gel electrophoresis using $7.5 \%$ polyacrylamide gels in $0.9 \mathrm{M}$ acetic acid containing $6 \mathrm{M}$ urea. Electrophoresis was run toward the cathode at $2 \mathrm{~mA}$ per gel for $4 \mathrm{~h}$. Gels were stained with Coomassie Blue.

Physical and chemical characterization. The concentration of lactoferrin in monkey milk was determined by rocket immunoelectrophoresis (22) in $1 \%$ sodium borohydride treated agarose gels in 0.025 M Tris/Tricine buffer, $\mathrm{pH}$ 8.6 (Bio Rad Laboratories, Richmond, $\mathrm{CA}$ ) using an antibody raised to the purified monkey lactoferrin. The agarose was obtained from Bio Rad Laboratories and treated to eliminate charged groups by the method of Lönnerdal and Låås (23). Antibody to monkey lactoferrin was raised in rabbits by Antibodies, Inc. (Davis, CA) using six injections of lactoferrin in Freund's complete adjuvant. Electrophoresis was carried out for $3 \mathrm{~h}$ at $300 \mathrm{v}$ and maximum current. The plate was washed and stained as described (24). Standards of known monkey lactoferrin concentrations were used to determine lactoferrin concentration in the milk samples. Concentrations in human milk were determined by the same method using antibody to human lactoferrin which was purchased from Dako Immunoglobulins (Copenhagen, Denmark). Human lactoferrin was prepared from pooled human milk obtained from healthy lactating donors.

Immunodiffusion was performed to investigate cross-reactivity of lactoferrin from several species. Monkey lactoferrin antibody was placed in the center well of a $1 \%$ agarose gel surrounded by wells containing milk samples from several species (human, monkey, cow, sheep, goat, dog, rat). Milk was obtained from healthy animals at the U.C. Davis animal facilities. The plate was left in a humid chamber for 3 days to allow diffusion. The plate was then processed as described above.

Amino acid analysis was performed following hydrolysis with hydrochloric acid in a sealed tube at $110^{\circ} \mathrm{C}$ for 24 and $48 \mathrm{~h}$ with performic acid oxidation for cysteine and methionine determination. Analysis was performed on a Durrum Model D-500 amino acid analyzer in $0.2 \mathrm{M}$ sodium citrate with $\beta$-thienyl alanine as the internal standard $(25,26)$. The amino acid sequence of the $\mathrm{N}$-terminus of monkey lactoferrin was determined on a Beckman $890 \mathrm{M}$ sequencer using $0.1 \mathrm{M}$ quadrol containing polybrene. Identification was obtained using high-performance liquid chromatography by the method of Bhown et al. (27) with confirmation by thin-layer chromatography by the method of Kulbe (28).

The carbohydrate component of monkey lactoferrin was investigated using colorimetric assays for the monosaccharides reported to be present in human lactoferrin (29). Total hexose was determined with the anthrone method (30). Mannose, galactose, and fucose were quantified as reported by Finch et al. (31) after acid hydrolysis in $2 \mathrm{~N} \mathrm{HCl}$ at $100^{\circ} \mathrm{C}$ for $1 \mathrm{~h}$. N-acetyl glucosamine was determined after acid hydrolysis as described by Gatt and Berman (32), and $\mathrm{N}$-acetyl neuraminic acid was quantified by the method of Schauer (33).

\section{RESULTS}

Physical and chemical characteristics of monkey lactoferrin were compared to those of human lactoferrin after purification of the protein from pooled monkey milk. By two chromatographic steps pure lactoferrin was obtained from monkey milk; DEAE-Sephadex chromatography gave a preliminary separation (Fig. 1), while final purification was achieved by Heparin-Sepharose affinity chromatography (Fig. 2). Lactoferrin eluted with

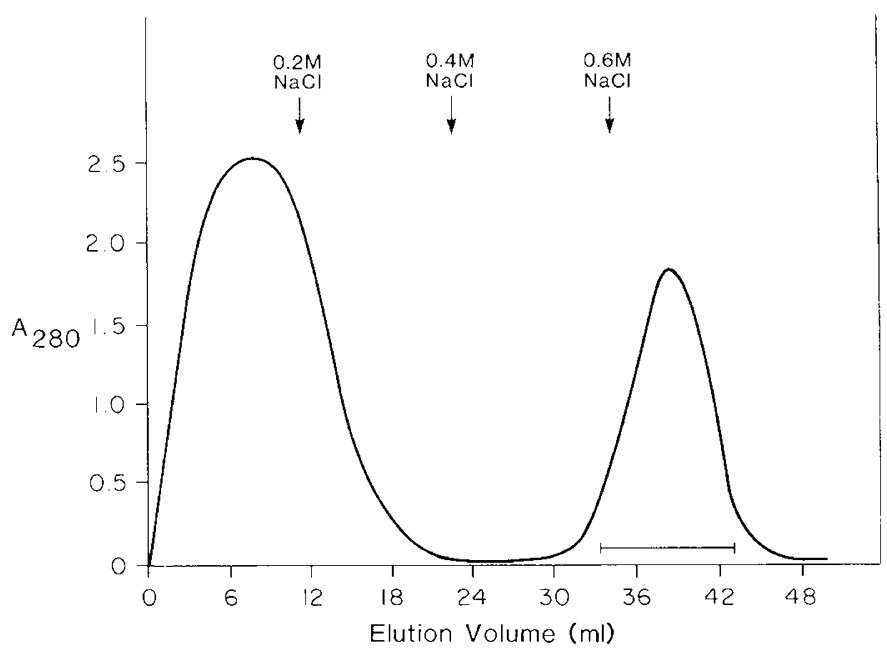

Fig. 2. Purification of lactoferrin by heparin-Sepharose affinity chromatography. The pure lactoferrin eluted with $0.6 \mathrm{M} \mathrm{NaCl}$.

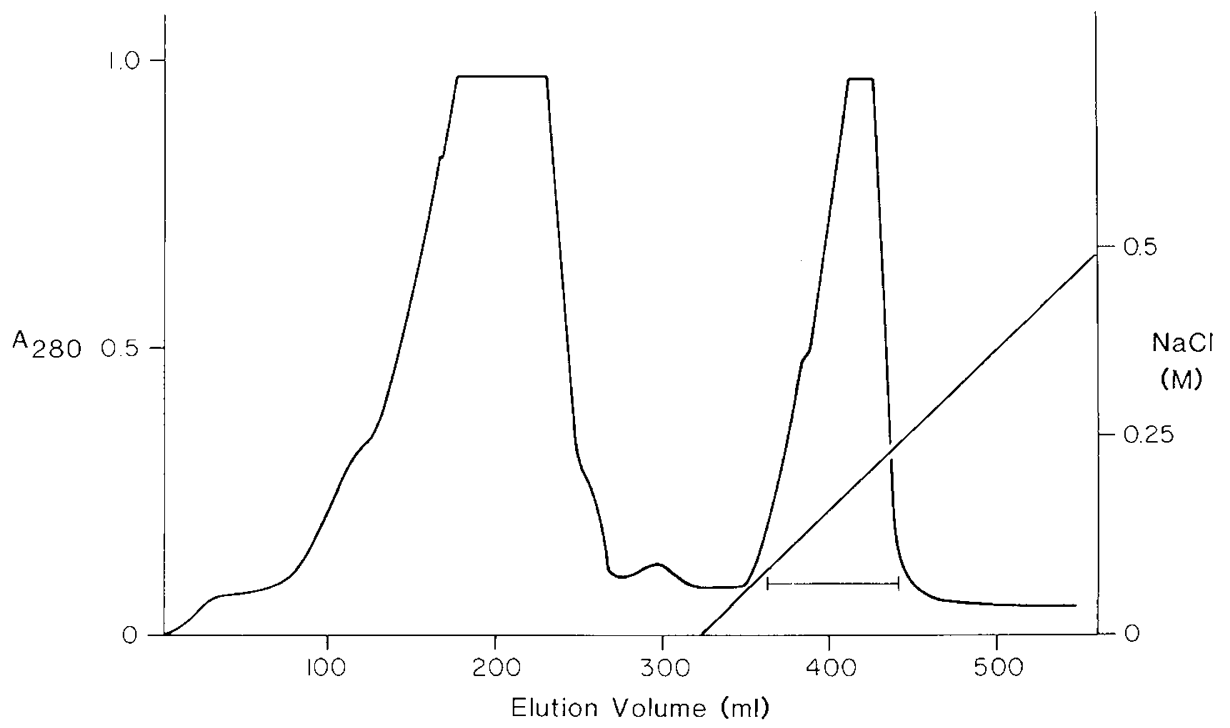

Fig. 1. Ion exchange chromatography on DEAE-Sephadex A-25. The lactoferrin peak is identified by the bar. 

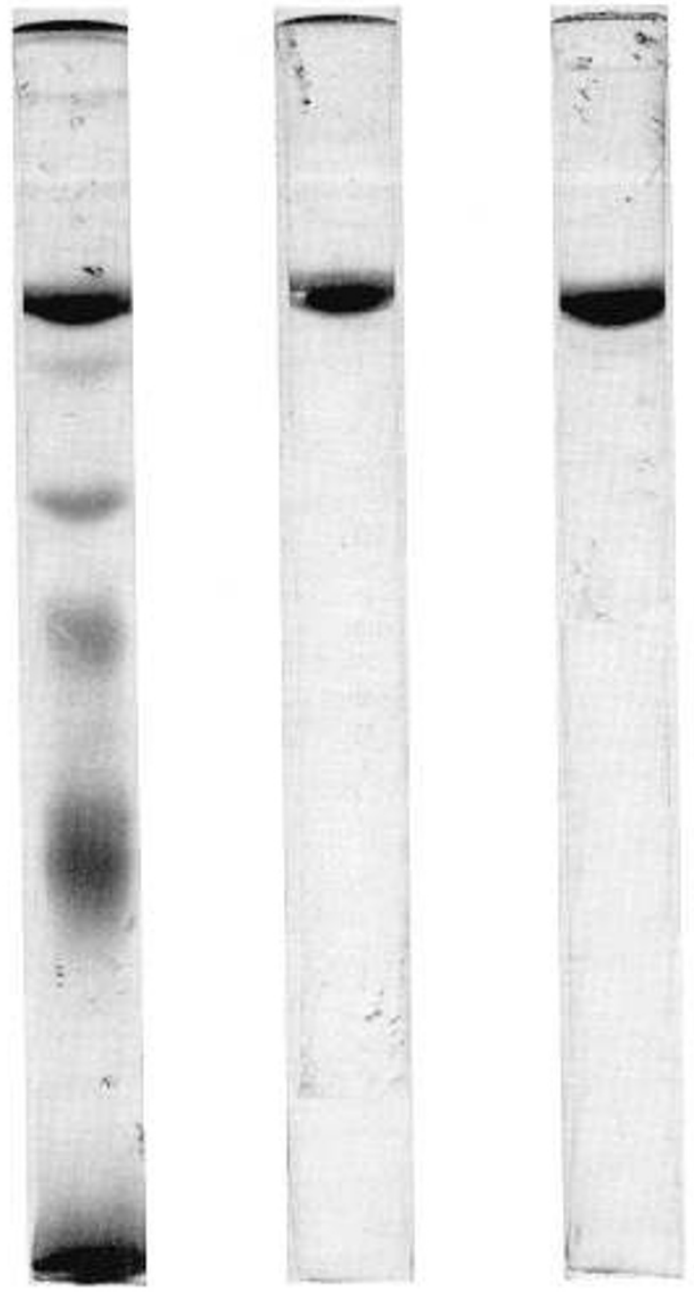

Table 2. Amino acid composition of monkey and human lactoferrin

\begin{tabular}{lcc}
\hline & \multicolumn{2}{c}{ Mol amino acid/mol protein } \\
\cline { 2 - 3 } & $\begin{array}{c}\text { Monkey } \\
\text { lactoferrin }\end{array}$ & $\begin{array}{c}\text { Human } \\
\text { lactoferrin* }\end{array}$ \\
\hline Aspartate & 72 & 67 \\
Threonine & 31 & 34 \\
Serine & 43 & 52 \\
Histidine & 9 & 12 \\
Glutamate & 67 & 68 \\
Proline & 34 & 36 \\
Glycine & 61 & 50 \\
Alanine & 73 & 61 \\
Valine & 50 & 41 \\
Isoleucine & 15 & 14 \\
Leucine & 62 & 53 \\
Tyrosine & 29 & 19 \\
Phenylalanine & 30 & 30 \\
Lysine & 47 & 44 \\
Arginine & 40 & 44 \\
Methionine & 1.2 & 3 \\
Cysteine & 23 & 26 \\
\hline
\end{tabular}

* Data from Montreuil et al. (34).

Table 3. Structure of $N$-terminus of human, monkey, and bovine lactoferrin

\begin{tabular}{ll}
\hline & \\
Human Lf* & $\mathrm{NH}_{3}$-gly-arg-arg-arg ser-val-gin-trp-cys-ala-val \\
Monkey Lf & $\mathrm{NH}_{3}$-ala-arg-arg-arg-ser-val-arg-X \\
Bovine Lf* & $\mathrm{NH}_{3}$-ala-pro-arg-val \\
\hline
\end{tabular}

* Data from Wang et al. (35).

+ Not determined by amino acid sequencing.

concentration in monkey milk of $1.73 \mathrm{mg} / \mathrm{ml}$ and in human milk of $1.82 \mathrm{mg} / \mathrm{ml}$ (Table 1 ).

Amino acid composition of monkey and human lactoferrin is compared in Table 2 . The profile for the isolated monkey lactoferrin is very similar to previously published values for human lactoferrin (34). Human milk lactoferrin has been reported to have an unusual $\mathrm{N}$-terminal, with four consecutive arginine residues (35). In contrast, bovine lactoferrin does not possess this highly basic N-terminal structure. Our analysis of monkey lactoferrin (Table 3) shows an amino acid sequence similar to that of human lactoferrin, with three consecutive arginine residues.

The content of the various monosaccharides in monkey lactoferrin as compared with human lactoferrin is given in Table 4. Total hexose and N-acetyl glucosamine content of the two glycoproteins is similar with monkey lactoferrin containing somewhat less galactose, fucose, and sialic acid and relatively more mannose.

Immunodiffusion was carried out to assess antigenic characteristics of lactoferrin from several species. This gives an indication of structural similarity of the lactoferrin molecules. With monkey lactoferrin antibody in the center well a precipitin band of identity was visible with human and monkey milk, signifying that the antibody could not distinguish between the human and the monkey protein. An additional band formed with the monkey lactoferrin, indicating further recognition of unknown determinants by the monkey antibody. No reaction occurred with milk samples from cow, goat, sheep, dog, or rat (Fig. 4). Identical results were obtained when antibody to human lactoferrin was placed in the center well. to be pure by polyacrylamide gel electrophoresis (Fig. 3). It can monkey milk, as it does in human milk. In addition, migration of monkey and human lactoferrin in the polyacrylamide gels is identical.

Concentration of lactoferrin in several mature monkey and human milk samples was determined by rocket immunoelectrophoresis. The results indicate very similar lactoferrin concentrations in mature monkey and human milk with an average 
Table 4. Carbohydrate composition of monkey and human lactoferrin

\begin{tabular}{lcc}
\hline & \multicolumn{2}{c}{$\begin{array}{c}\text { Mol monosaccharide/mol } \\
\text { protein }\end{array}$} \\
\cline { 2 - 3 } \multicolumn{1}{c}{ Monosaccharide } & $\begin{array}{c}\text { Monkey } \\
\text { lactoferrin }\end{array}$ & $\begin{array}{c}\text { Human } \\
\text { lactoferrin* }\end{array}$ \\
\hline Galactose & 2.2 & 4.2 \\
Mannose & 9.4 & 6.0 \\
Fucose & 0.8 & 2.2 \\
Total hexoses & 12.4 & 12.4 \\
N-Acetyl glucosamine & 8.2 & 8.3 \\
N-Acetyl neuraminic acid & 1.4 & 2.3 \\
\hline
\end{tabular}

* Data from Legrand et al. (29).

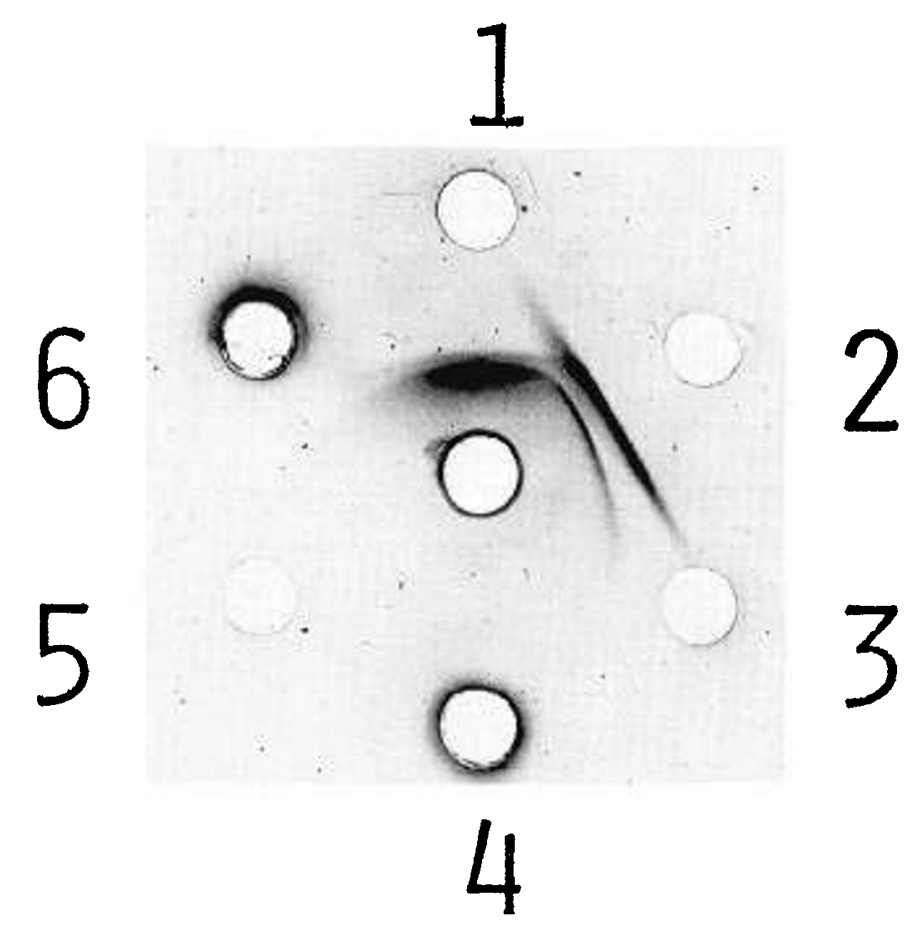

Fig. 4. Immunodiffusion of milk from various species against the antibody to monkey lactoferrin. Center well-monkey lactoferrin antibody; 1 , human milk; 2, monkey milk; 3, cow's milk; 4, sheep milk; 5 , goat milk; 6 , dog milk. Rat milk not shown.

\section{DISCUSSION}

In the present study we have examined the characteristics of lactoferrin from monkey milk in order to assess the suitability of its use in the study of iron absorption from milk. Pure monkey lactoferrin was isolated by ion exchange chromatography followed by affinity chromatography on Heparin-Sepharose. As can be seen on the polyacrylamide gels (Fig. 3), lactoferrin comprises a major whey protein in monkey milk, as it does in human milk, compared to the minor band seen in cow's whey. Monkey milk is similar to human milk in its high content of lactoferrin as determined by immunoelectrophoresis. This is in contrast to most other mammals, whose milks contain significantly lower concentrations of lactoferrin, 10-100 times less than the amounts seen in human milk (19). Again in contrast to bovine lactoferrin, human and monkey lactoferrin have similar sequences at the $\mathrm{N}$ terminal of the protein, each containing a highly basic terminal segment. Carbohydrate composition of the two glycoproteins is also similar. In studies examining the glycans of serum transfer- rins from several species and lactoferrins from human, bovine, and goat milks Spik et al. (36) have found fucose to be present only in human lactoferrin. Therefore, our finding of the presence of fucose in monkey lactoferrin is another demonstration of the similarity of human and monkey lactoferrin in contrast to other species.

Our data show the immunological characteristics of human and monkey lactoferrin to be very similar. A precipitation band, indicating immunological identity, formed between human and monkey milk, demonstrating a high degree of homology between these two proteins. No band developed with the other milk samples.

Lactoferrin has been investigated for its potential role as a vehicle for iron transport and absorption in the infant. An in vitro study by Cox et al. (17) demonstrated that of various ironbinding proteins (human lactoferrin, bovine lactoferrin, ovotransferrin, human serum transferrin) only human lactoferrin had the ability to deliver iron to the intestinal mucosa of normal adults. In a study with piglets it was shown that iron from lactoferrin was absorbed at a faster rate than iron as iron sulfate (37). Using iron-deficient weanling mice, lactoferrin iron was found to be bioavailable and to bring hematological parameters back to normal levels (38). These studies suggest a role for lactoferrin in facilitating iron transport across the brush border.

In a study with rats, Huebers et al. (39) concluded that lactoferrin inhibits iron absorption. Using intestinal loops they showed that human lactoferrin was poorly taken up by the mucosal cell. However, the rat does not appear to be a valid model for studying the role of lactoferrin in iron absorption. The major iron-binding protein in rat milk is transferrin, with lactoferrin being present in an extremely low concentration. In addition, the use of the nonhomologous system by Huebers et al. (39) (human lactoferrin in a rat system) is a limitation since significant species differences in lactoferrin structure and probably function may affect the results.

Significant evidence has accumulated regarding the mechanism of iron donation to cells by transferrin. The model, as proposed by Morgan (40) and supported by morphological (41) and isotopic data (42), proposes that transferrin binds to a specific membrane receptor, that the transferrin-receptor complex is internalized by endocytosis, that the iron is released inside the cell, and that the apotransferrin exits from the cell. This model has since been demonstrated in many cell types and species (4346). A mechanism for iron donation similar to the model proposed for transferrin can be envisioned for lactoferrin in the brush border membrane and is supported in part by the finding of immunologically intact lactoferrin in the feces of breast fed infants $(12,13)$.

In summary, the mechanism of iron uptake into mucosal cells remains unclear. Data by Cox et al. (17) give evidence for specific receptors for lactoferrin in the small intestine. In addition, in a preliminary study we have recently shown specific binding of monkey milk lactoferrin to receptors in the brush border (47). Studies demonstrating high bioavailability of lactoferrin-iron and the fact that the protein seems to be protected against proteolysis in the gastrointestinal tract of the infant provide additional support for a role of lactoferrin in iron absorption. We have observed that the characteristics of monkey lactoferrin, as opposed to lactoferrin from other species, are quite similar to those of human lactoferrin. The concentration of lactoferrin in monkey milk is high, facilitating the extraction of relatively large amounts of the protein from monkey milk. Elucidation of the role of lactoferrin in iron absorption in the suckling infant and its role in inflammation and bacteriostasis may be possible using the monkey as an experimental model.

\section{REFERENCES}

1. McMillan J, Landaw S. Oski F 1976 Iron sufficiency in breast-fed infants and the availability of iron from human milk. Pediatrics 58:686-691

2. Saarinen U, Siimes M, Dallman P 1977 Iron absorption in infants: high 
bioavailability of breast milk iron as indicated by the extrinsic tag method of iron absorption and by the concentration of serum ferritin. J Pediatr $91: 36-39$

3. Saarinen U 1978 Need for iron supplementation in infants on prolonged breast feeding. J Pediatr 93:177-180

4. Lönnerdal B. Keen C. Hurley L 1981 Iron. copper, zinc and manganese in milk. Ann Rev Nutr 1:149-174

5. Underwood EJ 1977 Iron in animal tissues and fluids. In: Underwood EJ (ed) Trace elcments in human and animal nutrition. Academic Press. New York. p 23

6. Masson PL. Heremans JF. Dive C 1966 An iron-binding protein common to many external secretions. Clin Chem Acta 14:735-739

7. Masson PL. Heremans JF. Schonne E 1969 Lactoferrin. an iron-binding protein in neutrophil leukocytes. J Exp Med 130:643-654

8. Mazurier J. Spik G 1980 Comparative study of the iron-binding properties of human transferrins. I. Complete and sequential iron saturation and desaturation of the lactotransferrin. Biochim Biophys Acta 629:399-408

9. Bullen JJ, Rogers HJ. I.eigh L 1972 Iron-binding proteins in milk and resistance to Escherichia coli infection in infants. Br Med J 1:69-75

10. Bluard-Deconinck I-M. Williams J. Evans RW. Van Snick J Osinski PA. Masson PL 197I Iron-binding fragments from the N-terminal and C-terminal regions of human lactoferrin. Biochem J 171:321-327

11. Line WF. Sly DA. Bezkorovainy A 1976 Limited cleavage of human lactoferrin with pepsin. Int J Biochem 7:203-208

12. Davidson I.A. Lomnerdal B 1985 Lactoferrin and secretory $\operatorname{Ig} \wedge$ in the feces of exclusivcly breast-fed infants. Am J Clin Nutr 41:852

13. Spik G. Brunct B. Mazurier-Dehaine C. Fontainc G. Montreuil J 1982 Characterization and properties of the human and bovine lactotransferrins extracted from the facces of newborn infants. Acta Paediatr Scand 71:979-985

14. Birgens HS. Hansen NE. Karle H. Kristensen LO 1983 Receptor binding of lactoferrin by human monocytes. Br J Hacmatol 54:383-39!

15. Boxer LA. Haak RA. Yang H-H. Wolach JB. Whitcomb JA, Butterick CJ. Bachner RL 1982 Membrane-bound lactoferrin alters the surface properties of polymorphonuclear leukocytes. J Clin Invest 70:1049-1057

16. Van Snick JL. Masson PL 1976 The binding of human lactoferrin to mouse peritoneal cells. J Exp Med 144:1568-1580

17. Cox TM. Mazurier J. Spik G. Montreuil J. Peters T 1979 lron binding proteins and influx of iron across the duodenal brush border. Evidence for specific lactoferrin receptors in the human intestine. Biochim Biophys Acta 588:120_128

18. I.onnerdal B. Forsum E. Hambracus L 1976 A longitudinal study of the protcin. nitrogen. and lactose content of human milk from well-nourished Swedish mothers. Am J Clin Nutr 29:1127-1133

19. Masson P. Heremans J 1971 Lactoferrin in milk from different species. Comp Biochem Physiol B39:119-129

20. Masson P. Heremans J 1968 Mctal-combining properties of human lactoferrin. I. The involvement of bicarbonate in the reaction. Eur $J$ Biochem 6:579584

21. Blackberg L. Hernell O 1980 Isolation of lactoferrin from human whey by a single chromatographic step. FEBS Lett 109:180-184

22. Laurell C-B 1966 Quantitative cstimation of proteins by electrophoresis in agarose gel containing antibodies. Anal Biochem 15:45-52

23. Lönnerdal B. I.åăs T 1976 Improved agarose for immunoelectrophoresis. Anal Biochem 72:527-532

24. Wecke B 1973 General remarks on principles, equipment, reagents and procedures. In: Axclsen N. Kr $\phi$ ll J. Weeke B (eds) A manual of quantitative immunoclectrophoresis. Universitetsforlaget. Oslo, Norway. pp 30-33

25. Hirs CHW (1967) Determination of cystine as cysteic acid. In: Colowick SP Kaplan NO (eds) Methods in Enzymology 11. Academic Press. New York. $\mathrm{pp} 59-62$
26. Pisano JJ. Bronzert TJ. Brewer HB Jr 1972 Advances in the gas chromatographic analysis of amino acid phenyl- and methylthiohydantoins. Anal Biochem 45:43-59

27. Bhown AS, Mole JE. Weissinger A. Bennett JC 1978 Methanol solvent svstem for rapid analysis of phenylthiohydantoin amino acids by high-pressure liquid chromatography. J Chromatogr ] 48:532-535

28. Kulbe KD 1974 Micropolyamide thin-layer chromatography of phenylthiohydantoin amino acids (PTH) at subnanomolar level. A rapid microtechnique for simultancous multisample identification after automated Fdman degradations. Anal Biochem 59:564-573

29. Legrand D. Mazurier J, Metz-Boutigue M-H, Jolles J. Jolles P. Montreui] J. Spik G 1984 Characterization and localization of an iron-binding 18-KDa glycopeptide isolated from the $\mathrm{N}$-terminal half of human lactotransferrin. Biochim Biophys Acta 787:90-96

30. Brin M 1966 Transketolase: Clinical aspects. In: Colowick SP. Kaplan NO (eds) Methods in Enzymology 9. Academic Press, New York pp 506-514

31. Finch PR. Yuen R. Schachter H. Moscarello MA 1969 Enzymatic methods for the micro assay of 1)-mannose. I)-glucose. 1)-galactose. and I-fucose from acid hydrolyzates of glycoproteins. Anal Biochem 31:296-305

32. Gatt R. Berman ER $1966 \mathrm{~A}$ rapid procedure for the estimation of amino sugars on a micro scale. Anal Biochem 15:167-17!

33. Schaucr R 1978 Characterization of sialic acids. In: Colowick SP. Kaplan NO (eds) Methods in En⿳mology 50. Academic Press. New York. pp 64-89

34. Montreuil J. Spik G. Monsigny M. Descamps J. Biserte G. Dautrevaux M 1965 Etude comparéc de la composition en oses et en amino-acides de la transferrine et de la lactoferrine humaines. Experientia 21:254-256

35. Wang C-S. Chan W-Y. Kloer HU 1984 Comparative studies on the chemical and immunochemical propertics of human milk, human pancreatic juice and bovine milk lactoferrin. Comp Biochem Phvsiol 78B: 575-580

36. Spik G. Coddeville B. I.egrand D. Mazurier J. Leger D. Goavec M. Montreuil $\mathrm{J} 1985$ A comparative study of the primary structure of glycans from various sero- lacto-, and ovotransferrins. Role of human lactotransferrin glveans In: Spik G. Montreuil J. Crichton RR. Marurier J (eds) Proteins of iron storage and transport. Elsevier Science Publishers. Amsterdam. pp 47-51

37. Fransson G-B. Thorén-Tolling K. Jones B. Hambraeus L. Lönnerdal B 1983 Absorption of lactoferrin-iron in suckling pigs. Nutr Res $3: 373-384$

38. Fransson G-B. Keen CL. Lönnerdal B 1983 Supplementation of milk with iron bound to lactoferrin using weanling mice. I. Effect on hematology ane tissue iron. J Pediatr Gastroenterol Nutr 2:693-700

39. Huebers HA. Huebers E. Csiba E. Rummel W. Finch CA 1983 The significance of transferrin for intestinal iron absorption. Blood 61:283-290

40. Morgan EH 1974 Transferrin and transferrin iron. In: Jacobs A. Worwood M (eds) Iron in Biochemistry and Medicine. Academic Press. New York. pp $30-71$

41. Hemmaplardh D. Morgan EH 1977 The role of endocytosis in transferrin uptake by reticulocytes and bone marrow cells. Br J Haematol 36:85-96

42. Sibille J-C. Octave J-N. Schncider Y-J. Tronet $A$. Crichton R 1982 Transferrin protein and iron uptake by cultured hepatocytes. FEBS Lett 150:365-369

43. Brown PJ. Molloy CM. Johnson PM 1982 Transferrin receptor affinity and iron transport in the human placenta. Placenta 3:21-28

44. Klausner RD, Ashwell G, van Renswoude J. Hartford JB, Bridges KR 1983 Binding of apotransferrin to K562 cells: explanation of the transferrin cycle. Proc Natl Acad Sci USA 80:2263-2266

45. Lim BC. Morgan EH 1984 Transferrin endocytosis and the mechanism of iron uptake by reticulocytes in the toad (Bufo marinus). Comp Biochem Phvsiol 79A:317-323

46. Page MA. Baker E. Morgan EH 1984 Transferrin and iron uptake by rat hepatocytes in culture. Am J Physiol 246:G26-G33

47. Davidson LA. L.önnerdal B 1985 Specific binding of monkey milk lactoferrin to its brush border receptor. Fed Proc 44:1673 